\title{
Putusan Tentang Pemidanaan Terhadap Pelaku Tindak Pidana Penadahan
}

\author{
Lestiyana, Elly Sudarti \\ Fakultas Hukum, Universitas Jambi, Indonesia \\ Author's Email Correnspondence: Listianacute97@gmail.com
}

\section{ABSTRAK}

Artikel ini bertujuan untuk mengetahui dan menganalisis putusan dalam tindak pidana penadahan. Penelitian ini menggunakan metode penelitian yuridis normatif. Keputusan Pengadilan Negeri Sarolangun menunjukkan dalam penjatuhan pidana, hakim belum menerapkan ketentuan sanksi pidana yang terdapat dalam Undang-Undang secara maksimal. Hal ini dapat dilihat dari pemidanaan yang dijatuhkan terhadap pelaku penadahan kurang dari 1 (satu) tahun penjara, sementara ancaman maksimal dari tindak pidana penadahan adalah 4 (empat) tahun penjara. Hal ini mengakibatkan pemidanaan tidak akan memberikan efek jera bagi pelaku.
Kata Kunci: Pemidanaan; putusan; tindak pidana

\section{ARTICLE HISTORY}

Submission: 18 December 2019

Accepted: 31 December 2020

Publish: 07 February 2020

KEYWORDS: Criminal offender; criminalization; verdict

\begin{abstract}
This article aims to find out and analyze the verdict of criminal offence. The research methods is normative research. The Sarolangun District Court's decision shows that in a criminal sentence, the judge did not apply the provisions of criminal sanctions contained in the law to the maximum. This can be seen from the punishment imposed on perpetrators of detention of less than 1 (one) year in prison, while the maximum threat of criminal offense is 4 (four) years in prison. This resulted in the punishment will not give a deterrent effect for the offender.
\end{abstract}

\section{A. Pendahuluan}

Artikel ini membahas mengenai pemidanaan yang diterapkan oleh majelis Hakim di wilayah Pengadilan Negeri Sarolangun tentang kasus tindak pidana penadahan dari tahun 2017 hingga tahun 2018. Pembahasan ini diperlukan karena dewasa ini kasus kejahatan banyak sekali terjadi dan yang paling dominan adalah jenis tindak pidana terhadap harta kekayaan, khususnya yang termasuk didalamnya adalah tindak pidana penadahan dengan berbagai macam bentuk dan modus operandinya yang semakin kompleks. Mengingat banyaknya kasus tindak pidana penadahan, bukan saja masalah perorangan atau kelompok tertentu, tetapi juga menjadi masalah nasional. Kasus seperti ini dapat mengancam stabilitas nasional, melunturkan ketahanan nasional dan 
dikhawatirkan dapat mengganggu kelangsungan pembangunan nasional yang sedang digalakan dewasa ini1 ${ }^{1}$.

Terlepas dari dampak yang ditimbulkan akibat tindak pidana penadahan ini, bagi para penadah, alasan untuk melakukan kejahatannya adalah karena ingin memperoleh atau mendapatkan keuntungan untuk dirinya sendiri maupun orang lain dengan cara melakukan "Pemudahan" seseorang untuk berbuat kejahatan. Hal ini disebabkan karena dengan adanya penadah sebagai penampung hasil tindak pidana, memberikan peluang atau kemudahan bagi pelaku tindak pidana untuk memperoleh keuntungan. Dapat dikatakan memperoleh keuntungan karena pelaku tindak pidana tidak harus menjual barang hasil tindak pidana tersebut ke konsumen secara langsung, tetapi dapat disalurkan melalui penadah².

Dalam perkembangannya, tindak pidana penadahan yang sering terjadi di wilayah Pengadilan Negeri Sarolangun dewasa ini adalah tindak pidana penadahan terhadap kendaraan bermotor yang didapat dari kejahatan pencurian. Hal ini sebagaimana dapat kita ketahui dari data perkara tindak pidana di Pengadilan Negeri Sarolangun dapat dikemukakan bahwa ada 6 (enam) perkara tindak pidana penadahan yang diajukan ke Pengadilan Negeri Sarolangun yaitu 4 (empat) perkara pada tahun 2018 dan 2 (dua) perkara pada tahun 2017, yang mana dari 6 (enam) perkara tersebut, sebanyak 4 (empat) perkara tindak pidana penadahan dengan barang bukti berupa sepeda motor.

Selain itu, dari 6 (enam) putusan tentang perkara tindak pidana penadahan yang dikeluarkan oleh Pengadilan Negeri Sarolangun, pidana yang dijatuhkan oleh majelis hakim hanya berkisar antara 4 (empat) bulan hingga 6 (enam) bulan penjara terhadap terdakwa atau dalam artian hukumannya rata-rata dibawah dari 1 (satu) tahun penjara, padahal dalam Pasal 480 ayat (1) KUHP ancaman hukuman yang diberikan adalah 4 (empat) tahun penjara ${ }^{3}$. Hal ini tentunya mengakibatkan sanksi yang diberikan untuk pelaku tindak pidana penadahan belum maksimal dan belum menimbulkan efek jera bagi para pelaku.

Untuk dapat dibuktikan bahwa seorang pelaku telah memenuhi unsur tindak pidana penadahan, maka salah satu unsur yang harus terlebih dahulu diketahui adalah unsur sengaja dan unsur culpa, yang berarti bahwa si pelaku penadahan memang mengetahui atau dapat dianggap patut harus dapat menyangka asalnya barang dari kejahatan ${ }^{4}$, sebagai contoh kendaraan bermotor yang dijual tidak dilengkapi dengan surat-surat yang sah seperti Surat Tanda Nomor Kendaraan (STNK) dan Bukti

1 H. Cecep Wiharma, "Perspektif Penegakan Hukum Terhadap Barang-barang Ilegar Di Pasar Bebas, Jurnal Ilmu Hukum, 2, 1 (2016), hlm. 761.

2 Repository.unhas.ac.id/bitstream/handle/123456789/4490/JURNAL.docx???/sequence, tanggal akses 20 Maret 2019, Pukul 18.19 WIB.

3 Pasal 480 ayat (1) KUHP: "Dengan hukuman penjara selama-lamanya empat tahun atau denda sebanyak-banyak Rp 900,- (sembilan ratus rupiah), karena sebagai sekongkol, barangsiapa yang membeli, menyewa, menerima tukar, menerima gadai, menerima sebagai hadiah, atau karena hendak mendapat untung, menjual, menukarkan, menggadaikan, membawa, menyimpan atau menyembunyikan suatu benda, yang diketahuinya atau patut disangkanya diperoleh karena kejahatan".

4 Untuk dapat mengetahui bahwa suatu barang itu berasal dari kejahatan memang cukup sulit, akan tetapi dapat kita ketahui dalam prakteknya, terdapat kriteria-kriteria tertentu mulai dari kelengkapan kepemilikan surat-surat apakah ada atau tidak, harga barang apakah wajar atau dibawah pasaran pada umumnya dan transaksi yang dilakukan apakah secara sembunyi-sembunyi atau terang-terangan. 
Kepemilikan Kendaraan Bermotor (BPKB), sehingga pembeli dapat menyangka bahwa kendaraan tersebut berasal dari kejahatan.

Dengan adanya penadah terhadap kendaraan bermotor akan memudahkan seseorang untuk melakukan kejahatan-kejahatan yang lainnya, dikarenakan ada kelompok yang menerima, membeli atau menampung hasil kejahatan ${ }^{5}$. Sehingga akan menjadi salah satu faktor pemicu terhadap meningkatnya angka kejahatan pencurian kendaraan bermotor karena pelaku tidak kesulitan untuk memasarkan barang yang ia curi kepada mereka yang mau menampung benda hasil kejahatan ${ }^{6}$. Oleh sebab itu, dikaitkan dengan pelaku tindak pidana penadahan, maka yang menjadi rumusan masalah disini adalah bagaimanakah pertimbangan hakim Pengadilan Negeri Sarolangun dalam menjatuhkan putusan pemidanaan terhadap pelaku tindak pidana penadahan agar memberikan efek jera?

Dalam membahas persoalan tersebut, artikel ini akan terlebih dahulu memaparkan pengaturan tindak pidana penadahan dan selanjutnya menganalisis putusan tentang pemidanaan yang diterapkan oleh Hakim Pengadilan Negeri Sarolangun terhadap para pelaku tindak pidana penadahan. Metode yang diterapkan dalam penelitian ini yaitu metode penelitian yuridis normatif. Menggunakan pendekatan penelaahan yakni pendekatan perundang-undangan, konseptual dan kasus7. Data yang digunakan meliputi data primer yang diperoleh dari peraturan perundang-undangan dan putusan dari Pengadilan Negeri Sarolangun; dan data sekunder yang diperoleh dari karya tulis ilmiah, artikel dan buku referensi terkait. Analisis dilakukan melalui tahapan mendekskripsikan, interpretasi dan kesimpulan.

\section{B. Metode Penelitian}

Jenis penelitian yang digunakan dalam penelitian ini adalah penelitian hukum normatif, dimana penelitian ini berangkat adanya isu hukum. Penelitian hukum dilakukan untuk menghasilkan argumentasi,teori, atau konsep baru sebagai preskripsi dalam menghadapi masalah yang dihadapiPenelitian hukum normatif merupakan jenis penelitian hukum yang diperoleh dari studi kepustakaan, dengan menganalisis suatu permasalahan hukum melalui peraturan perundang-undangan, literatur-literatur dan bahan-bahan referensi lainnya.

\section{Pembahasan}

\section{Aspek Hukum Tindak Pidana Penadahan di Indonesia}

Perbuatan "penadahan" itu sangat erat hubungannya dengan kejahatankejahatan seperti pencurian, penggelapan, atau penipuan. ${ }^{8}$ Kata Penadahan sendiri adalah suatu kerja tadah, yang menunjukan kejahatanitu atau subjek pelaku. ${ }^{9}$ Di

5 Sebagaimana dari data yang didapat, bahwa dewasa ini telah banyak ditemukan kios-kios maupun kaki lima yang menyuplai suku cadang kendaraan motor bekas. Dengan begitu kemungkinan besar adanya suku cadang atau komponen kendaraan yang diperoleh para pedagang merupakan hasil kejahatan dari pelaku pencurian kendaraan bermotor.

6 Coby Mamahit,. "Aspek Hukum Pengaturan Tindak Pidana Penadahan dan Upaya Menanggulanginya Di Indonesia”, Jurnal Ilmu Hukum, 23, 08 (2017), hlm. 72.

7 Peter Mahmud Marzuki, Penelitian Hukum (Jakarta: Kencana Prenada Media Group, 2016), hlm. 133.

8 Coby Mamahit, Op. Cit, hlm. 77.

9 Sugiyono Umar Ma'ruf, "Penangan Perkara Tindak Pidana Penadahan di Pengadilan Negeri Semarang, Jurnal Hukum Khaira Umar, Vol. 12 No. 3, 2017, hlm. 686. 
Belanda, penadahan sendiri disebut Heling ${ }^{10}$. Penadahan dapat dikatakan tindak pidana berantai, maksudnya adalah untuk adanya penadahan maka harus terlebih dahulu didahulukan dengan kejahatan lainnya, karena setelah seseorang melakukan kejahatan, terhadap barang-barang hasil kejahatan tersebut ada yang digunakan sendiri, ada yang diberikan atau dihadiahkan dan sering pula digunakan untuk mendapatkan keuntungan dalam bentuk uang, barang atau lain-lain ${ }^{11}$.

Penadahan dalam istilah hukum pidana merupakan perbuatan yang sengaja dilakukan oleh seseorang atau sekelompok orang untuk memperoleh keuntungan terhadap barang yang asalnya dari kejahatan, dengan jalan membeli, menyewa, menerima tukar, menerima gadai, menerima sebagai hadiah, atau karena hendak mendapat untung, menjual, menukarkan, menggadaikan, membawa, menyimpan atau menyembunyikan barang12. Pengertian tindak pidana penadahan menurut Satochid Kartanegara juga disebut sebagai tindak pidana pemudahan, yakni karena perbuatan menadah telah mendorong orang lain untuk melakukan kejahatan-kejahatan yang mungkin saja tidak akan ia lakukan, seandainya tidak ada orang yang bersedia menerima hasil kejahatan ${ }^{13}$.

Pengaturan tentang rumusan dan sanksi pidana perbuatan penadahan dimuat dalam Bab XXX KUHP dan merupakan salah satu delik kejahatan terhadap harta kekayaan tentang delik pemberi bantuan sesudah terjadi kejahatan ${ }^{14}$. Penadahan selalu bersinggungan dengan barang yang berasal dari kejahatan dan merupakan salah satu kejahatan terhadap harta kekayaan yang cukup sulit untuk ditanggulangi dewasa ini15. Tindak pidana penadahan yang dirumuskan dalam Pasal 480 ayat 1 KUHP mencakup beberapa komponen, diantaranya yaitu:

a) Subjek yaitu barangsiapa.

b) Perbuatan, yaitu membeli, menyewa, menerima tukar, menerima gadai, menerima sebagai hadiah, atau karena hendak mendapat untung, menjual, menukarkan, menggadaikan, membawa, menyimpan atau menyembunyikan suatu benda, yang diketahuinya atau patut disangkanya diperoleh karena kejahatan.

c) Objek yaitu sesuatu benda/barang.

d) Batin terhadap objek yaitu yang diketahuinya atau secara patut harus dapat diduganya, bahwa benda tersebut telah diperoleh karena kejahatan.

10 Heling dalam bahasa Belanda berarti "sekongkol" yang mengacu kepada unsur batin sebagaimana yang dimaksud dalam Pasal 480 ayat (1) KUHP. Esensi terpenting dari pasal ini yakni: "terdakwa harus mengetahui atau patut dapat menyangka", bahwa asal muasal barang yang diperoleh itu merupakan barang yang "gelap" yang berasal dari kejahatan dan bukanlah merupakan barang yang "terang".

11 PAF.Lamintang, Delik-Delik Khusus Kejahatan-Kejahatan Terhadap Harta Kekayaan (Bandung: Sinar Baru Bandung, 1989), hlm. 337.

12 Andi Hamzah, Delik-delik Tertentu (Speciale Delicten) di Dalam KUHP (Jakarta: Sinar grafika, 2015), hlm. 124.

13 Adami Chazawi, Kejahatan Terhadap Harta Benda (Jawa Timur: Bayumedia Publishing, 2006), hlm. 205.

14 Delik pemberi bantuan disini bukan sebagaimana yang dimaksud pada Pasal 56 KUHP karena menurut Pasal 56 KUHP orang yang dikategorikan memberi bantuan kejahatan itu adalah sebelum atau pada saat kejahatan itu berlangsung, sedangkan menurut Pasal 480 KUHP, seseorang dinyatakan memberi bantuan kejahatan tersebut pada saat sesudah kejahatan itu terjadi.

15 M. Kholil, "Tinjauan Empiris Pasal 480 KUHP Tentang Penadahan Menyangkut Hak-Hak Konsumen Dalam Pasal 4 Undang-Undang Nomor 8 Tahun 1999 Tentang Perlindungan Konsumen" Jurnal Hukum Bisnis, 1, 1 (2018), hlm. 54. 
Lebih lanjut, penadahan juga dapat kita temukan dasar hukumnya dalam Pasal 481 KUHP yakni tentang penadahan sebagai bentuk kebiasaan, artinya harus paling tidak telah dilakukan lebih dari satu kali atau minimal dua kali, karena jika perbuatan tersebut dilakukan hanya sekali maka perbuatan tersebut tidak dikenai Pasal 481 KUHP melainkan dikenai pasal 480 KUHP. Mengenai ancaman hukuman pidananya pun lebih berat yakni 7 (tujuh) tahun penjara. Kemudian, penadahan juga dimuat dalam Pasal 482 KUHP yakni penadahan ringan yang nilai kerugiannya kurang dari Rp 600,- (enam ratus rupiah) yang selanjutnya diubah ketetapan nilai barangnya dengan diterbitkannya Peraturan Mahkamah Agung Nomor 2 tahun 2012 terhadap kisaran nilai kerugian yang ditimbulkan yakni $\mathrm{Rp} 2.500 .000,00$ - (dua juta lima ratus ribu rupiah) dengan hukuman maksimal 3 (tiga) bulan penjara.

\section{Dasar Pertimbangan Hakim Dalam Menjatuhkan Pidana Penjara Dalam Putusan Perkara Tindak Pidana Penadahan.}

Beberapa dasar pertimbangan yang digunakan hakim dalam menetapkan pidana terhadap pelaku tindak pidana penadahan di Pengadilan Negeri Sarolangun antara lain:

\section{a. Pertimbangan yang bersifat yuridis}

Pertimbangan yuridis adalah pertimbangan hakim yang didasarkan pada faktafakta yuridis yang terungkap dalam persidangan dan oleh Undang-Undang dinyatakan harus dimuat di dalam putusan sebagai berikut:

\section{Dakwaan Jaksa Penuntut Umum}

Sepanjang tahun 2017 dan 2018 yang diteliti di Pengadilan Negeri Sarolangun terdapat 6 (enam) perkara penadahan yang diuraikan dengan tabel sebagai berikut:

Tabel

Dakwaan JPU Pada Perkara Penadahan di Wilayah Pengadilan Negeri Sarolangun

\begin{tabular}{|c|c|c|c|c|c|}
\hline No & Nomor Perkara & $\begin{array}{c}\text { Pasal Yang } \\
\text { Didakwakan }\end{array}$ & Barang Bukti & $\begin{array}{l}\text { Tuntutan } \\
\text { JPU }\end{array}$ & Putusan \\
\hline 1 & $\begin{array}{l}\text { 191/Pid.B/ } \\
\text { 2017/PN Srl }\end{array}$ & $\begin{array}{l}\text { Pasal } 480 \text { ayat } \\
\text { ke- } 1 \text { KUHP }\end{array}$ & $\begin{array}{l}1 \text { unit sepeda } \\
\text { motor merek } \\
\text { Honda Scoopy } \\
\text { warna merah }\end{array}$ & $\begin{array}{l}5 \text { bulan } \\
\text { penjara }\end{array}$ & $\begin{array}{l}4 \text { bulan } \\
\text { penjara }\end{array}$ \\
\hline 2 & $\begin{array}{l}\text { 183/Pid.B/201 } \\
\text { 7/PN Srl }\end{array}$ & $\begin{array}{l}\text { Pasal } 480 \text { ayat } \\
\text { ke-1 KUHP }\end{array}$ & $\begin{array}{l}1 \text { Unit Sepeda } \\
\text { Motor Honda Revo } \\
\text { warna hitam }\end{array}$ & $\begin{array}{l}10 \text { bulan } \\
\text { penjara }\end{array}$ & $\begin{array}{l}6 \text { bulan } \\
\text { penjara }\end{array}$ \\
\hline 3 & $\begin{array}{l}\text { 10/Pid.B/2018 } \\
\text { /PN Srl }\end{array}$ & $\begin{array}{l}\text { Pasal } 480 \text { ayat } \\
\text { ke- } 1 \text { KUHP }\end{array}$ & $\begin{array}{l}1 \text { unit sepeda } \\
\text { motor merek } \\
\text { Kawasaki ninja } \\
\text { warna hijau }\end{array}$ & $\begin{array}{l}6 \text { bulan } \\
\text { penjara }\end{array}$ & $\begin{array}{l}4 \text { bulan } \\
\text { penjara }\end{array}$ \\
\hline 4 & $\begin{array}{l}\text { 11/Pid.B/2018 } \\
\text { /PN Srl }\end{array}$ & $\begin{array}{l}\text { Pasal } 480 \text { ayat } \\
\text { ke-1 KUHP }\end{array}$ & $\begin{array}{l}1 \text { unitsepeda } \\
\text { motor merek } \\
\text { Kawasaki ninja } \\
\text { warna hijau }\end{array}$ & $\begin{array}{l}6 \text { bulan } \\
\text { penjara }\end{array}$ & $\begin{array}{l}4 \text { bulan } \\
\text { penjara }\end{array}$ \\
\hline 5 & $\begin{array}{l}\text { 18/Pid.B/2018 } \\
\text { /PN Srl }\end{array}$ & $\begin{array}{l}\text { Pasal } 480 \text { ayat } \\
\text { ke-1 KUHP }\end{array}$ & $\begin{array}{l}48 \text { tandan buah } \\
\text { kelapa sawit }\end{array}$ & $\begin{array}{l}7 \text { bulan } \\
\text { penjara }\end{array}$ & $\begin{array}{l}6 \text { bulan } \\
\text { penjara }\end{array}$ \\
\hline
\end{tabular}


PAMPAS: Journal of Criminal Law Vol. 1, No. 1

\begin{tabular}{llllll}
\hline 6 & 148/Pid.B/201 & Pasal 480 ayat & 1 unit Mobil Pick & 5 bulan & 3 bulan \\
& 8/PN Srl & ke-1 KUHP & Up Mitsubishi & penjara & 15 hari \\
& & Strada & & penjara \\
& & berwarna Putih & & \\
& & Solid. & & \\
& &
\end{tabular}

Sumber Data: Pengadilan Negeri Sarolangun

Berdasarkan tabel diatas, Terdakwa telah didakwa oleh Jaksa Penuntut Umum dengan dakwaan yang berbentuk Tunggal ${ }^{16}$, melanggar Pasal 480 ayat (1) KUHP tentang Penadahan. Sebagaimana dakwaan yang diajukan oleh Jaksa Penuntut Umum berbentuk Tunggal, maka Hakim mempertimbangkan terlebih dahulu mengenai perbuatan terdakwa tersebut apakah telah memenuhi unsur dari pasal yang diajukan meliputi:

1. Unsur Barang Siapa

2. Unsur membeli, menyewa, menerima tukar, menerima gadai, menerima sebagai hadiah, atau karena hendak mendapat untung, menjual, menukarkan, menggadaikan, membawa, menyimpan atau menyembunyikan suatu benda, yang diketahuinya atau patut disangkanya diperoleh karena kejahatan

3. Yang diketahui atau patut disangkanya, bahwa barang tersebut diperoleh karena kejahatan.

Setelah semua unsur perbuatan penadahan telah terpenuhi kemudian majelis Hakim akan memberikan penilaian hukum sebagai berikut:

Bahwa terkait 6 (enam) perkara yang penulis teliti yaitu putusan Pengadilan Negeri Sarolangun tentang tindak pidana penadahan dari tahun 2017 hingga 2018, Jaksa memilih dakwaan yang berbentuk tunggal. Pengambilan jenis dakwaan ini dikarenakan perbuatan yang didakwakan kepada masing-masing terdakwa hanya tertuju pada 1 (satu) perbuatan saja yaitu penadahan sebagaimana dimuat dalam Pasal 480 ayat (1) KUHP yang tidak memungkinkan untuk Jaksa menerapkan jenis dakwaan pengganti lainnya.

Lebih lanjut, terhadap pasal yang diterapkan oleh Jaksa pada surat dakwaannya, untuk kasus ini sendiri, Jaksa menerapkan Pasal 480 ayat (1) KUHP. Untuk penerapan pasal yang menjerat terdakwa pada kasus ini, harus terlebih dahulu diteliti lebih mendalam akar perbuatan yang dilakukan terdakwa, yang mana tindak pidana penadahan itu tidak hanya dimuat dalam Pasal 480 KUHP saja, melainkan juga dimuat dalam Pasal 481 KUHP dan Pasal 482 KUHP. Berdasarkan 6 (enam) perkara yang diteliti oleh penulis, sekiranya terdakwa telah mengetahui atau patut menduga bahwasanya barang yang ia transaksikan merupakan barang yang berasal dari pencurian maupun penggelapan ataupun penipuan. Jaksa tidak mendapatkan adanya

16 Dakwaan tunggal adalah dakwaan yang dibuat oleh Jaksa Penuntut Umum dengan hanya mendakwakan 1 (satu) perbuatan pidana yang berdiri sendiri atau tunggal kepada terdakwa. Menyangkut tentang surat dakwaan, menurut Pasal 143 KUHAP ada 2 (dua) syarat untuk dapat dibuatnya surat dakwaan, yang pertama adalah syarat formil meliputi format surat dakwaan yang didalamnya mencakup tanggal, identitas terdakwa, tanda tangan Jaksa, dan syarat yang kedua adalah syarat materil yang mencakup uraian tindak pidana yang didakwakan baik itu locus dan tempus delicti yang dibuat dengan cermat, jelas, dan lengkap. Jika dalam pembuatan surat dakwaan tidak mencakup beberapa hal diatas maka menurut Pasal 143 KUHAP surat dakwaan akan batal demi hukum. 
bukti yang menunjukkan bahwa perbuatan terdakwa tersebut adalah suatu kebiasaan atau telah berkali-kali melakukan penadahan maupun masuk ketagori penadahan ringan. Dengan demikian keputusan Jaksa yang mendakwa terdakwa dengan Pasal 480 ayat (1) KUHP.

Selain itu dapat dilihat bahwa keseluruhan dakwaan yang dibuat oleh Jaksa Penuntut Umum dengan barang bukti yang paling banyak adalah 4 (empat) perkara berupa sepeda motor dan 1 (satu) perkara berupa 1 unit mobil dan 1 (satu) perkara lagi berupa buah sawit, hal ini mengisyaratkan bahwa tindak pidana penadahan terhadap kendaraan bermotor masih dalam tahap kejahatan yang cukup tinggi terjadi di wilayah Kabupaten Sarolangun dan karena itu memerlukan perhatian yang khusus untuk diatasi oleh aparat penegak hukum.

Terkait hal ini, dari 6 (enam) perkara penadahan di Pengadilan Negeri Sarolangun, yang mana Jaksa mendakwa seluruh terdakwa dengan tuntutan pidana yang sangat bervariasi, dimulai dari 5 bulan hingga 10 bulan penjara. Jaksa disini berpendapat bahwa kejahatan penadahan ini bukanlah suatu kejahatan yang serius atau kejahatan yang berat sehingga Jaksa memberikan tuntutan kurang dari 1 (satu) tahun penjara atau tidak lebih dari 1 (satu) tahun penjara. Penulis menilai bahwa tuntutan yang dibuat oleh Jaksa Penuntut Umum tersebut kurang tepat, yang mana tuntutan tersebut tidak ada yang lebih dari 1 (satu) tahun penjara, padahal ancaman pidana maksimal tindak pidana penadahan ini adalah 4 (empat) tahun penjara. Meskipun tindak pidana penadahan bukan merupakan kejahatan berat, akan tetapi kejahatan penadahan dapat digolongkan kepada tindak pidana pemudahan, yang artinya penadahan akan memudahkan pelaku tindak pidana lain untuk menutupi kejahatannya, oleh sebab itu sanksi yang diberikan untuk pelaku tindak pidana ini juga harus berat pula.

\section{b. Fakta di Persidangan}

Fakta persidangan yang menjadi dasar pertimbangan hakim dalam menjatuhkan pidana salah satunya yaitu berdasarkan sistem pembuktian yang mencakup alat bukti sebagaimana dimuat dalam Pasal 184 ayat (1) KUHP yaitu:

a. Keterangan Saksi.

b. Keterangan Ahli.

c. Surat.

d. Petunjuk.

e. Keterangan Terdakwa.

Pada 6 (enam) putusan penadahan di Pengadilan Negeri Sarolangun yang diteliti terungkap bahwa alat bukti yang ada didalam persidangan adalah sebagai berikut ${ }^{17}$ :

a. Keterangan saksi

Keseluruhan saksi yang diajukan oleh Jaksa didalam persidangan merupakan saksi yang sah dan sesuai aturan hukum untuk dapat menyatakan keterangannya terhadap peristiwa pidana yang telah terjadi yangmana peristiwa tersebut ia alami, ia ketahui dan ia dengar sendiri sebagai berikut:

17 Pasal 183 KUHAP: "Hakim tidak boleh menjatuhkan pidana kepada seseorang kecuali apabila dengan sekurang-kurangnya dua alat bukti yang sah ia memperoleh keyakinan bahwa suatu tindak pidana benar-benar terjadi dan bahwa terdakwalah yang salah melakukannya Dalam penelitian diatas, diperoleh fakta dipersidangan yaitu dari 6 (enam) perkara yang diajukan di Pengadilan Negeri Sarolangun hanya terdapat 2 (dua) alat bukti, yakni keterangan saksi dan keterangan terdakwa. 
- Bahwa saksi kenal dengan para terdakwa.

- Bahwa benar saksi saat diperiksa dipersidangan dalam keadaan sehat jasmani dan rohani.

- Bahwa saksi membenarkan telah terjadi tindak pidana penadahan yang diperbuat oleh terdakwa sebagaimana telah tercantum di surat dakwaan yang dibuat oleh Jaksa.

- Bahwa saksi membenarkan barang bukti yang terungkap dipersidangan merupakan barang yang berasal dari kejahatan.

b. Keterangan terdakwa

- Bahwa keterangan saksi dibenarkan oleh terdakwa.

Keterangan dari terdakwa sekaligus sebagai pelaku tindak pidana dalam 6 (enam) perkara penadahan di wilayah Pengadilan Negeri Sarolangun, terungkap keterangan terdakwa yang didapat dalam persidangan diuraikan sebagai berikut:

- Terdakwa sedang dalam kondisi fisik yang sehat jasmani dan rohani, bersedia untuk diperiksa dan akan memberikan keterangan yang sebenarbenarnya dan selama menjalani pemeriksaan tidak perlu didampingi Penasehat Hukum.

- Bahwa terdakwa membenarkan keterangan yang diberikan oleh para saksi.

- Bahwa benar terdakwa mengakui sebagai pelaku atau penadah sebagaimana yang didakwakan oleh Jaksa.

- Terdakwa juga mengetahui barang bukti yang terungkap dipersidangan merupakan barang yang berasal dari kejahatan.

Menurut penulis, dari 6 (enam) perkara yang diteliti mengenai alat bukti yang terungkap dipersidangan, yang mana didalamnya sudah terpenuhi sekurangkurangnya dua alat bukti yang sah maka hakim boleh menjatuhkan pidana terhadap terdakwa karena menurut keyakinannya, terdakwa telah bersalah melakukan tindak pidana yang didakwakan kepadanya.

\section{c. Fakta Sosiologis}

Dalam hal ini hakim mempertimbangkan hal-hal yang memberatkan dan meringankan terdakwa didalam putusannya:

Hal-hal yang memberatkan

Hal-hal yang memberatkan yang dipertimbangkan oleh hakim untuk menjatuhkan pemidanaan terhadap masing-masing terdakwa dari 6 (enam) putusan yang penulis teliti, yaitu perbuatan terdakwa meresahkan dan menimbulkan kerugian bagi korban18.

Hal-hal yang meringankan

Ha-hal yang meringankan yang dipertimbangkan oleh hakim untuk menjatuhkan pemidanaan terhadap masing-masing terdakwa dari 6 (enam) putusan yang penulis teliti, yaitu19:

- Terdakwa berlaku sopan, berterus terang mengakui dan menyesali perbuatannya dan berjanji tidak akan mengulanginya lagi.

- Terdakwa belum pernah dihukum.

- Terdakwa merupakan tulang punggung keluarga.

18 Dalam KUHP terdapat tiga hal yang dijadikan alasan memberatkan pidana, yaitu karena suatu jabatan (Pasal 52 KUHP), residive atau pengulangan (tidak diatur secara umum dalam KUHP tetapi diatur secara khusus untuk kelompok tindak pidana tertentu baik kejahatan maupun pelanggaran), dan samenloop atau gabungan (Pasal 65 dan 66 KUHP).

19 Menurut KUHP alasan-alasan yang dapat meringankan pidana yaitu, percobaan (pasal 53 ayat), membantu atau medleplegend (pasal 57 ayat), dan belum dewasa (Pasal 47). 
Selanjutnya setelah terdakwa telah terbukti melakukan tindak pidana penadahan yang didakwakan oleh Jaksa, sebelum pidana dijatuhkan oleh hakim, terlebih dahulu hakim harus mempertimbangan secara sosiologis dengan memperhatikan bagaimana sikap atau perilaku terdakwa, kondisi diri terdakwa, hal-hal yang memberatkan atau hal-hal yang meringankan terdakwa yang kemudian akan dipergunakan oleh hakim dalam setiap putusannya. Kemudian, hakim dalam menjatuhkan putusan harus mencerminkan keadilan bagi masyarakat.

Dalam 6 (enam) putusan Pengadilan Negeri Sarolangun, hakim memutuskan masing-masing terdakwa terbukti oleh hukum telah bersalah melakukan tindak pidana "barang siapa membeli, menyewa, menerima tukar, menerima gadai, menerima sebagai hadiah, atau karena hendak mendapat untung, menjual, menukarkan, menggadaikan, membawa, menyimpan atau menyembunyikan suatu benda yang diketahui atau sepatutnya harus diduga, bahwa diperoleh dari kejahatan" sebagaimana yang didakwakan oleh Jaksa Penuntut Umum. Mengenai penjatuhan pidana penjara oleh hakim, dalam 6 (enam) kasus ini hakim menjatuhkan pidana penjara lebih rendah dari tuntutan Jaksa Penuntut Umum yakni pidana yang berkisar antara 4 (empat) bulan hingga 6 (enam) bulan penjara.

Penjatuhan putusan pidana penjara yang cenderung rendah yang diputuskan oleh majelis hakim sebenarnya secara normative tidak melanggar aturan hukum. Sebab hakim dalam menjatuhkan putusan berdasarkan pada ancaman pidana yang dirumuskan dalam tiap pasal serta berdasarkan formulasi dakwaan dan tuntutan Jaksa. Dalam rumusan Pasal 480 Ayat 1 menyatakan ancaman pidana adalah paling banyak 4 tahun dan denda paling banyak sembilan ratus rupiah. Jika melihat dari aspek formulasi ancaman pidana bahwa hakim memiliki keleluasaan menjatuhkan pidana selama tidak melebihi 4 tahun. Sehingga ketika hakim menjatuhkan, pidana kurang dari satu tahun tentu saja tidak menjadi persoalan. Namun sebenarnya, hal tersebut menjadi, perhatian bagi hakim untuk benar- benar memutuskan besaran pidana bagi terdakwa. Disparitas yang tidak relevan dikhawatirkan terjadi ketika hakim, memutus dengan besaran pidana yang rendah tanpa dasar pertimbangan yang jelas. Dasar pemberian pidana yang dijatuhkan oleh hakim kepada terdakwa, harus mempertimbangkan aspek kesalahan, perbuatan terdakwa, dan aspek pelaku, sebab putusan tersebut akan menjadi preseden yang tidak baik. Dari aspek pemidanaan juga harus mendapat perhatian bagi hakim, sebab penjatuhan pidana yang dijatuhkan oleh hakim harus memenuhi tujuan-tujuan pemidanaan.

Mencermati dari 6 (enam) perkara penadahan yang diteliti, terdapat 1 (satu) perkara dengan pelaku merupakan Purnawirawan TNI. Jika ditinjau dari aspek pelaku, tentunya ada unsur pemberatan terhadap penjatuhan pidananya. Menurut penulis maka hakim bisa saja mengambil vonis diluar dari tuntutan jaksa. Secara substansi pemidanaan yang dijatuhkan oleh hakim belum memunculkan ruhnya sebuah keadilan. Berhukum secara substansial tidak lalu mengabaikan teks berhukum, yang sekarang sudah menjadi keniscayaan, melainkan agar hukumnya dapat menyejahterakan dan membahagiakan warganya ${ }^{20}$. Ditinjau dari aspek pemidanaan tidak terlepas dari tujuan yang ingin dicapai. Dari keenam putusan dari kurun waktu 2017 dan 2018, dapat

20 M. Zulfa Aulia, Hukum Progresif dari Satjipto Rahardjo: Riwayat, Urgensi, dan Relevansi, Undang: Jurnal Hukum, Volume 1 Nomor 1, 2018, Hal.170 https://ujh.unja.ac.id/index.php/home/issue/view/1. 
dicermati bahwa putusan tertinggi 6 bulan penjara dan putusan terendah 3 bulan penjara. Hakim memiliki pertimbangan tertentu ketika menetapkan besaran pidana, namun hal penting yang menjadi perhatian apakah dengan menetapkan besaran pidana yang relatif rendah memberikan dampak penjeraan bagi pelaku atau setidaknya mencegah orang lain untuk tidak melakukan kejahatan tersebut. Dampak dari pemidanaan harus memberikan respon secara langsung bagi masyarakat, dalam arti bahwa penegak hukum (dalam hal ini hakim) benar benar serius memberikan hukuman bagi pelaku supaya berjalannya prevensi general dari tujuan pemidanaan ini tercapai.

\section{Simpulan}

Artikel ini menyimpulkan, penerapan hukum pidana materil terhadap tindak pidana penadahan dalam 6 (enam) putusan di Pengadilan Negeri Sarolangun oleh Jaksa Penuntut Umum dan majelis Hakim telah sesuai. Dengan menerapkan jenis dakwaan tunggal yakni Pasal 480 ayat (1) KUHP menurut penulis sudah sesuai dikarenakan perbuatan dari masing-masing terdakwa memang hanya tertuju pada satu tindak pidana saja yaitu penadahan yang merujuk Pasal 480 ayat (1) KUHP. Akan tetapi, baik Jaksa dalam mengajukan tuntutan maupun majelis hakim dalam menjatuhkan pidana pada 6 (enam) putusan penadahan di Pengadilan Negeri Sarolangun dari tahun 2017 hingga 2018 hanya menjatuhkan tuntutan pidana kurang dari 1 (satu) tahun penjara yang tentunya tidak bisa menimbulkan penjeraan bagi para pelaku. Ditinjau dari aspek pemidanaan, penjatuhan pidana bagi pelaku adalah hal yang sangat penting sejalan dengan tercapainya tujuan pemidanaan.

\section{DAFTAR PUSTAKA}

\section{Dokumen Hukum}

Republik Indonesia. Undang-Undang Tentang Menyatakan Berlakunya UU NO. 1 Tahun 1946 RI Tentang Peraturan Hukum Pidana Untuk Seluruh Wilayah RI Dan Mengubah Kitab Undang-Undang Hukum Pidana, Nomor 73 Tahun 1958. LNRI Tahun 1958 Nomor 127. TLNRI Nomor 1660.

Republik Indonesia, Undang-Undang Tentang Pernyataan Berlaku Untuk Seluruh Wilayah RI KUHP UU No. 1 Tahun 1946 RI (Penjelasan dalam Tambahan Lembaran Negara RI Nomor 1660).

Republik Indonesia. Undang-Undang Tentang Hukum Acara Pidana. UU Nomor 8 Tahun 1981. LNRI Tahun 1981 Nomor 76. TLNRI Nomor 3209.

Republik Indonesia. Undang-Undang Tentang Kekuasaan Kehakiman, Nomor 48 Tahun 2009 (Lembaran Negara Republik Indonesia Tahun 2009 Nomor 157).

\section{Buku}

Chazawi, Adami. Kejahatan Terhadap Harta Benda. Jawa Timur: Bayumedia Publishing, 2006.

Hamzah, Andi. Delik-delik Tertentu (Speciale Delicten) di Dalam KUHP. Jakarta: Sinar grafika, 2015. 
Lamintang, P.A.F. Delik-delik Khusus Kejahatan-Kejahatan Terhadap Harta Kekayaan. Bandung: Sinar Baru Bandung, 1989.

Peter Mahmud Marzuki. Penelitian Hukum. Jakarta: Kencana Prenada Media Group, Edisi Revisi, 2013.

\section{Jurnal}

Mamahit, Coby. "Aspek Hukum Pengaturan Tindak Pidana Penadahan dan Upaya Menanggulanginya Di Indonesia”, Jurnal Ilmu Hukum, 23, 08 (2017): 72.

M. Kholil, “Tinjauan Empiris Pasal 480 KUHP Tentang Penadahan Menyangkut Hak-Hak Konsumen Dalam Pasal 4 Undang-Undang Nomor 8 Tahun 1999 Tentang Perlindungan Konsumen" Jurnal Hukum Bisnis, 1, 1 (2018): 54.

M. Zulfa Aulia, Hukum Progresif dari Satjipto Rahardjo: Riwayat, Urgensi, dan Relevansi, Undang: Jurnal Hukum, Volume 1 Nomor 1, 2018, https://ujh.unja.ac.id/index.php/home/issue/ view/1

Sugiyono Umar Ma'ruf, "Penangan Perkara Tindak Pidana Penadahan di Pengadilan Negeri Semarang, Jurnal Hukum Khaira Umar, Vol. 12 No. 3, 2017.

\section{Website}

http://m.hukumonline.com/klinik/detail/lt4f034e487/majalah-pembuktian-tindakpidana-penadahan/

repository.unhas.ac.id/bitstream/handle/123456789/4490/JURNAL.docx?sequence/ . 